\title{
Optimalisasi Pengereman Regeneratif dengan Perubahan Sudut Eksitasi pada Pulsa Tunggal
}

\author{
Nazila Kusumaningrum*, Slamet Riyadi*, Leonardus Heru Pratomo, dan Florentinus Budi Setyawan \\ Program Studi Teknik Elektro, Universitas Katolik Soegijapranata \\ Jl. Pawiyatan Luhur IV/1 Bendan Duwur, Semarang, 50234, Indonesia \\ *Corresponding author.Email: nazilakusuma14@gmail.com,ignslametriyadi6@gmail.com
}

\begin{abstract}
Most of the energy is wasted into heat energy due to conventional braking, so an optimal braking strategy is needed. A Regenerative braking utilizes the kinetic energy of the engine into electrical energy by changing the function of an electric machine into a generator. The regenerative braking system uses a Switched Reluctance Machine (SRM) which has several advantages; simple construction, does not require maintenance, and return energy to the battery. The method that can be used in the regenerative braking system of the SRM is the change of excitation angle to produce the maximum peak phase current. This study aims to optimize regenerative braking by changing the angle $\left(\theta_{\text {eks }}\right)$ using simple controls to produce energy that is greater than the battery voltage so that current may flow to the battery when braking occurs. The results of the analysis for method implementation were proven by testing the devices in the laboratory. Based on the results of the tests, the exact angle was obtained, namely the value of $\theta_{\text {eks }}=20^{\circ}$ and the value of $\theta_{\text {kom }}=170^{\circ}$ with an initial speed of 1822 RPM, reduced into 1522 RPM by braking process, which could produce a peak current of 12,5 A and a current flowing to the battery was $5 A$.
\end{abstract}

Keywords—back-emf, regenerative braking, SRM, excitation angle, comutation angle

\begin{abstract}
Abstrak- Sebagian besar energi terbuang menjadi energi panas akibat pengereman konvensional sehingga diperlukan strategi pengereman yang optimal. Pengereman regeneratif memanfaatkan energi kinetik pada mesin menjadi energi listrik dengan mengubah fungsi motor listrik menjadi generator. Sistem pengereman regeneratif menggunakan Switched Reluctance Machine (SRM) memiliki keunggulan konstruksi yang sederhana, tidak memerlukan perawatan, dan dapat mengembalikan energi ke baterai. Metode yang dapat digunakan pada sistem pengereman regeneratif pada SRM dengan mengubah sudut eksitasi untuk menghasilkan arus puncak fasa maksimal. Penelitian ini bertujuan mengoptimalkan pengereman regeneratif dengan mengubah nilai sudut eksitasi $\left(\theta_{\text {eks }}\right)$ menggunakan kendali sederhana untuk menghasilkan energi yang yang lebih besar dari tegangan baterai yang memungkinkan arus dialirkan ke baterai saat pengereman. Hasil analisis implementasi metode dibuktikan dengan pengujian alat di laboratorium. Berdasarkan hasil pengujian yang dilakukan diperoleh sudut presisi yaitu nilai $\theta_{\text {eks }}=20^{\circ}$ dan nilai $\theta_{\mathrm{kom}}=170^{\circ}$ dengan kecepatan awal sebesar 1822 RPM mengalami perlambatan karena proses pengereman menjadi 1522 RPM dapat menghasilkan arus puncak sebesar 12,5 A dan arus yang dialirkan ke baterai sebesar 5A.
\end{abstract}

Kata kunci- GGL balik, pengereman regeneratif, SRM, sudut eksitasi, sudut komutasi

\section{PENDAhUluan}

Kendaraan dengan mesin bakar meningkatkan polusi udara yang akan berdampak buruk pada kontinuitas hidup manusia. Penelitian mengenai kendaraan yang ramah lingkungan berbasis mesin listrik terus dikembangkan saat ini [1], [2] Kendaraan listrik memiliki kelebihan di antaranya tidak menimbulkan emisi karbon, kebisingan rendah, dan memiliki teknologi pengereman yang optimal [3]. Terdapat beberapa jenis pengereman yang digunakan pada kendaraan listrik diantaranya pengereman dinamik, pengereman anti-lock, pengereman hidraulik, dan pengereman regeneratif [4] - [6].

Pengereman regeneratif dapat menyerap energi kinetik yang terbuang saat pengereman konvensional dan dialirkan ke baterai untuk pengisian daya sehingga dapat memperpanjang jarak tempuh pada kendaraan listrik [7], [8]. Umumnya, energi kinetik banyak terbuang menjadi energi panas saat terjadi pengereman konvensional [9]. Sistem pengereman regeneratif mampu mengembalikan energi ke sumber baterai jika mesin listrik diubah fungsinya dari motor menjadi generator pada saat terjadi pengereman. Pengereman regeneratif pada Switched Reluctance Machine (SRM) dilakukan dengan mengubah sudut eksitasi yang memengaruhi torka dan nilai arus puncak fasa. Nilai torka yang dihasilkan bernilai negatif sehingga terjadi putaran rotor akan berlawanan dengan arah motor sehingga terjadi perlambatan kecepatan. Pada sistem pengereman regeneratif energi yang dihasilkan dari proses pengereman harus lebih besar dari tegangan baterai. Energi dari proses pengereman dalam bentuk arus yang dialirkan ke baterai sehingga terjadi pengisian daya saat terjadi pengereman konvensional.

Perubahan sudut eksitasi yang dilakukan juga memengaruhi nilai arus puncak fasa. Nilai arus puncak fasa yang kecil mengakibatkan energi yang dihasilkan dari generator bernilai kecil sehingga arus yang dialirkan ke baterai kurang optimal [10]. Metode perubahan sudut eksitasi yang presisi untuk 
menghasilkan nilai arus puncak fasa maksimal dapat dilakukan dengan beberapa sistem kendali seperti kendali histerisis di mana sistem kendali daya harus menyesuaikan arus referensi yang merupakan variable control [11]. Penentuan sudut fasa yang tidak tepat akan menghasilkan nilai arus puncak fasa yang kecil [12], [13]. Solusi dalam mengatasi permasalahan tersebut yaitu menggunakan algoritma sistem pengendalian yang lebih sederhana untuk mengoptimalkan sistem pengereman regeneratif dengan menggunakan profil induktansi sebagai acuan yang dapat menghasilkan arus puncak fasa yang lebih besar. Metode dilakukan dengan mengubah nilai $\theta_{\text {eks }}$ pada pesaklaran pulsa tunggal menggunakan fasilitas input capture.

Pada prinsipnya, SRM memerlukan injeksi arus pada belitan stator untuk menginduksi rotor. Rotor pada SRM yang digerakkan perlu dijadikan magnet sesaat agar stator menghasilkan gaya gerak listrik (GGL) [14]. Nilai dari GGL balik harus lebih besar dari tegangan baterai agar arus dapat dialirkan ke baterai pada saat pengereman. Pada kecepatan tinggi GGL balik akibat induksi elektromagnetik menjadi besar sehingga arus fasa terus meningkat [15]. Nilai GGL balik yang kecil mengakibatkan arus fasa menurun dengan cepat sehingga tidak ada arus yang dialirkan ke baterai [16]. Pengiriman arus ke baterai dapat optimal dengan menentukan sudut eksitasi $\left(\theta_{\text {eks }}\right)$ dan sudut komutasi $\left(\theta_{\mathrm{kom}}\right)$ dalam sistem kontrol digital. Sistem kontrol digital akan memudahkan dalam mengatur $\theta_{\text {eks }}$ dan $\theta_{\text {kom }}$ yang diperoleh menggunakan metode pulsa tunggal [16]. Metode ini menghasilkan energi yang lebih besar dari tegangan baterai.

Tujuan dari penelitian ini adalah mengoptimalkan sistem pengereman regeneratif dengan pengendalian yang sederhana yang dapat menghasilkan arus puncak fasa yang lebih besar. Metode dilakukan dengan mengubah nilai $\theta_{\mathrm{eks}}$ pada pensaklaran pulsa tunggal menggunakan fasilitas input capture. Hasil penelitian ini diverifikasi oleh pengujian perangkat keras di laboratorium.

\section{METODE}

Sistem pengereman regeneratif pada penelitian ini menggunakan mesin listrik jenis SRM. SRM mampu beroperasi pada kecepatan dan suhu yang tinggi karena rotornya terbuat dari inti besi sehingga banyak diaplikasikan pada kendaraan hybrid [17]. Selain itu, SRM juga mampu dioperasikan sebagai motor dan generator sehingga dapat digunakan pada pengoperasian pengereman regeneratif. Pengereman regeneratif mampu mengembalikan energi yang terbuang akibat pengereman jika mesin listrik diubah fungsinya dari motor ke generator. Sistem pengereman regeneratif pada SRM dengan metode pulsa tunggal dapat dioperasikan pada kecepatan tinggi. Ilustrasi pengereman regeneratif ditunjukkan pada Gambar 1.

Pada Gambar 1 ditunjukkan SRM dapat dioperasikan sebagai motor dan generator. Proses pengereman regeneratif dapat berjalan dengan sangat baik jika berada di turunan jalan di mana saat kendaraan berada pada turunan jalan kecepatan SRM akan meningkat sehingga SRM akan melakukan pengereman. Saat terjadi pengereman konvensional SRM akan dioperasikan sebagai generator. Generator inilah yang akan mengubah energi kinetik menjadi energi listrik sehingga dapat menghasilkan pengereman regeneratif. Pengereman regeneratif memanfaatkan energi yang terbuang akibat pengereman konvensional untuk pengisian daya ke baterai. Pemberian injeksi arus pada stator SRM dengan pengaturan sudut dapat diterapkan pada sistem pengereman regeneratif.

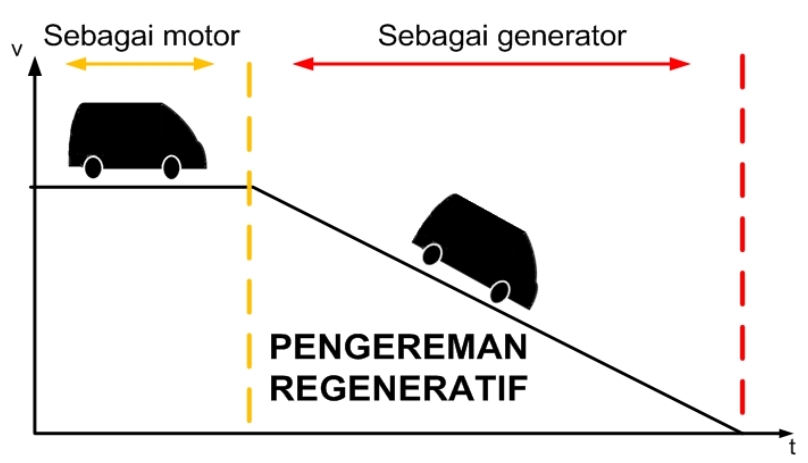

Gambar 1. Ilustrasi operasi pengereman regeneratif

Pada penelitian ini, SRM yang digunakan memiliki 12 stator dan 8 rotor dengan menggunakan konverter jenis asymmetric. Konverter ini menerapkan satu lengan pada dua saklar berfungsi untuk menghasilkan tegangan negatif saat saklar fasa dimatikan. Konstruksi SRM dan konverter asymmetric ditunjukkan pada Gambar 2.

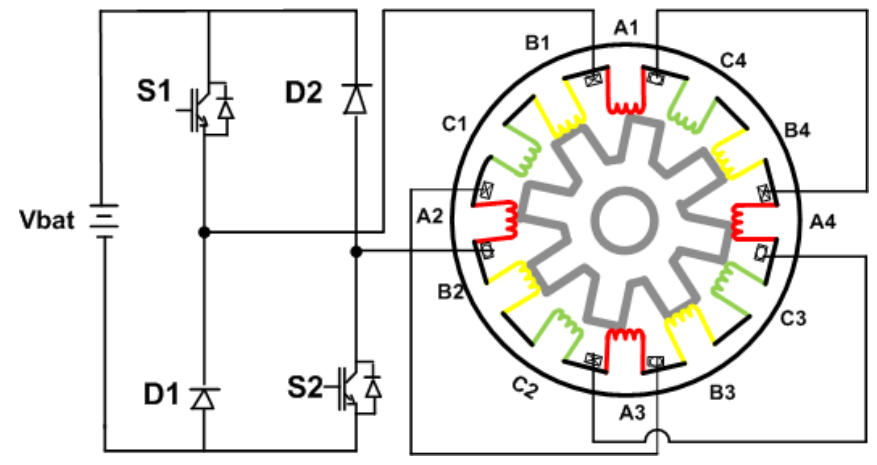

Gambar 2. Konstruksi SRM 12/8 dan konverter jenis asymmetric pada satu fasa

Proses pemberian arus pada stator dilakukan dengan mengubah $\theta_{\text {eks }}$ berdasarkan profil induktansi yang ditunjukkan pada Gambar 2. Sistem pengereman regeneratif pada saat stator A1-A2-A3-A4 diberi arus yaitu saat posisi rotor akan meninggalkan stator atau pada posisi induktansi turun dan menghasilkan torka negatif. Torka negatif itulah yang mengakibatkan adanya perlambatan pada kecepatan putar mesin dan energi dari pengereman dapat dialirkan ke baterai. Hubungan antara torka terhadap profil induktansi dinyatakan pada (1).

$$
T(\theta)=\frac{1}{2} \frac{\partial L}{\partial \theta} \times i^{2}
$$

di mana $T(\theta), \partial L, \partial \theta$, dan $i$ merupakan nilai torka, perubahan nilai induktansi, dan posisi rotor.

Gambar 3 menunjukkan profil induktansi yang digunakan sebagai acuan dalam menentukan sudut fasa. Profil induktansi diperoleh dengan cara memberikan sinyal PWM pada stator SRM yang akan menghasilkan gelombang impuls arus. Gelombang impuls arus yang dihasilkan stator SRM berbanding terbalik dengan profil induktansi. Daerah $\theta_{\mathrm{a}} \sim \theta_{\mathrm{eks}}$ atau pada saat induktansi naik merupakan daerah motoring karena menghasilkan nilai torka positif sehingga SRM akan dioperasikan sebagai motor. Sedangkan daerah $\theta_{\mathrm{eks}} \sim \theta_{\mathrm{kom} 3}$ merupakan daerah generating yang menghasilkan nilai torka negatif sehingga SRM dioperasikan sebagai generator. Metode pengereman regeneratif dilakukan saat induktansi turun. 


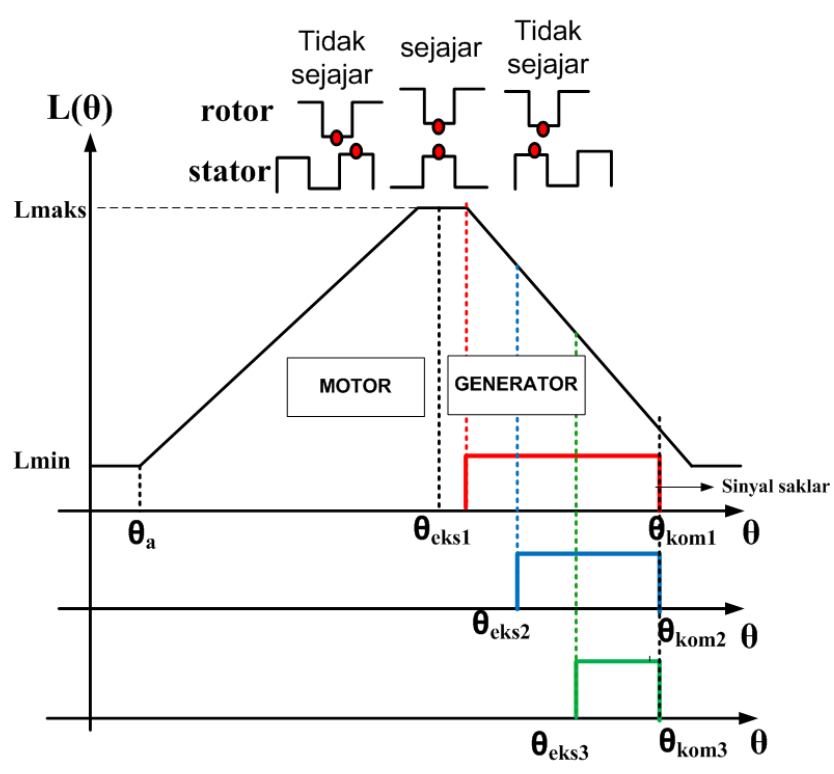

Gambar 3. Perubahan sudut eksitasi terhadap profil induktansi

Metode perubahan $\theta_{\text {eks }}$ yang dilakukan dengan tiga kondisi yaitu kondisi pertama nilai $\theta_{\text {eks1 }}$ berada pada posisi induktansi akan menuju minimum atau posisi rotor akan meninggalkan stator. Nilai $\theta_{\text {eks2 }}$ berada pada induktansi minimum atau posisi rotor meninggalkan stator dan akan mendekati stator fasa yang lain, dan nilai $\theta_{\text {eks } 3}$ berada pada induktansi minimum atau posisi rotor mendekati stator fasa lain. Pada ketiga kondisi tersebut akan menghasilkan sinyal pensaklaran yang berbeda.

Penelitian ini menggunakan konverter asymmetric dengan metode pensaklaran pulsa tunggal yang terbagi menjadi dua mode operasi yaitu mode magnetisasi dan mode demagnetisasi. Mode magnetisasi yaitu pemberian injeksi arus pada stator untuk menghasilkan medan magnet antara stator dan rotor. Sedangkan mode demagnetisasi terjadi ketika terdapat proses arus yang dialirkan ke baterai. Konverter asymmertric ditunjukkan pada Gambar 4. Mode magnetisasi dan mode demagnetisasi ditunjukkan pada Gambar 5 dan Gambar 6.

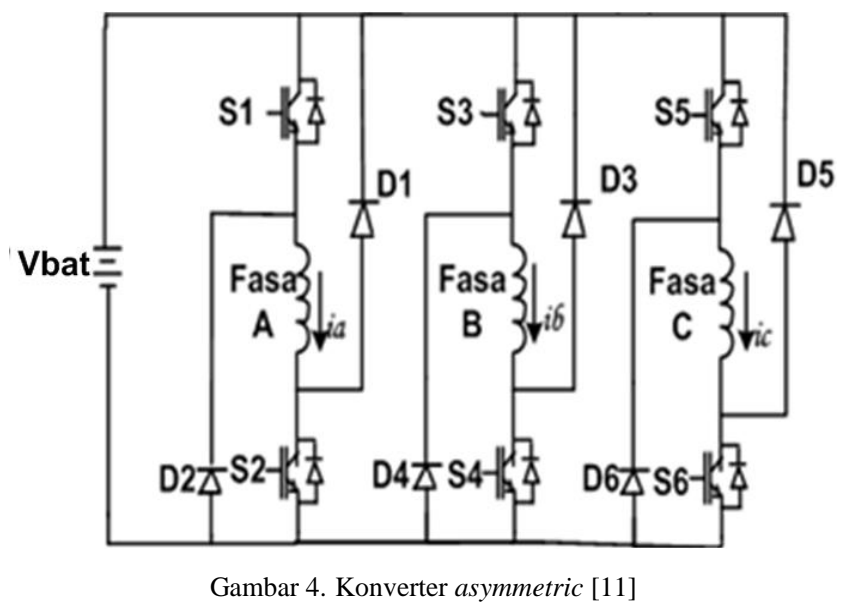

Mode magnetisasi menghasilkan GGL balik pada stator di mana S1 dan S2 dinyalakan secara bersamaan. Arus mengalir dari baterai melalui saklar fasa menuju belitan fasa dan arus induktor akan naik. Pada mode operasi magnetisasi didapatkan pada (2).

$$
\text { Vbat }=i R+\omega L \frac{d i}{d \theta}
$$

di mana $V_{b a t}, i, R, \omega, L$, dan $d \theta$ merupakan tegangan baterai, nilai arus fasa, resistansi, kecepatan putar rotor, nilai induktansi, dan nilai perubahan sudut.

Mode demagnetisasi menghasilkan tegangan negatif saat S1 dan S2 dimatikan. Tegangan negatif didapatkan karena adanya arus yang kembali ke baterai sehingga dapat dinyatakan pada (3).

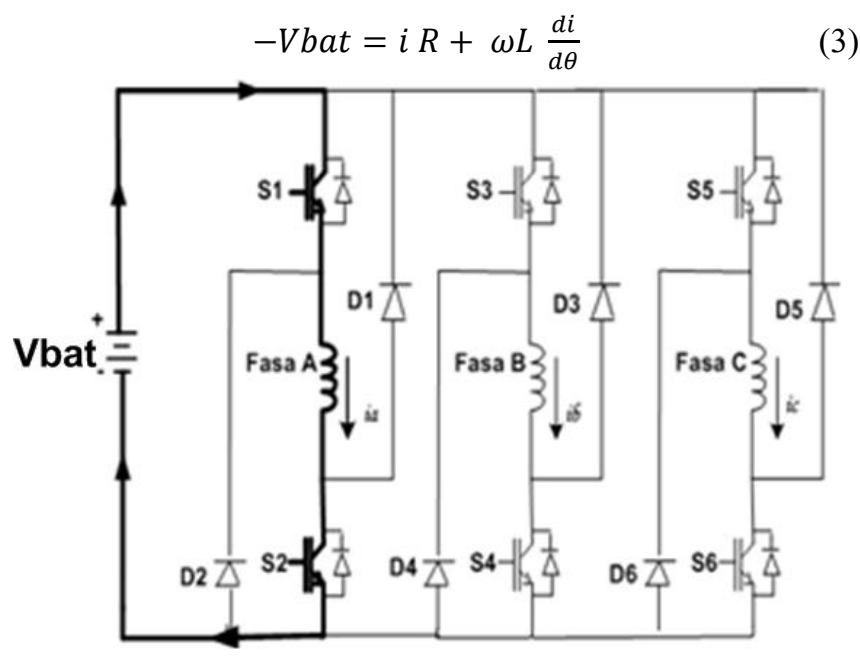

Gambar 5. Mode magnetisasi pada salah satu fasa

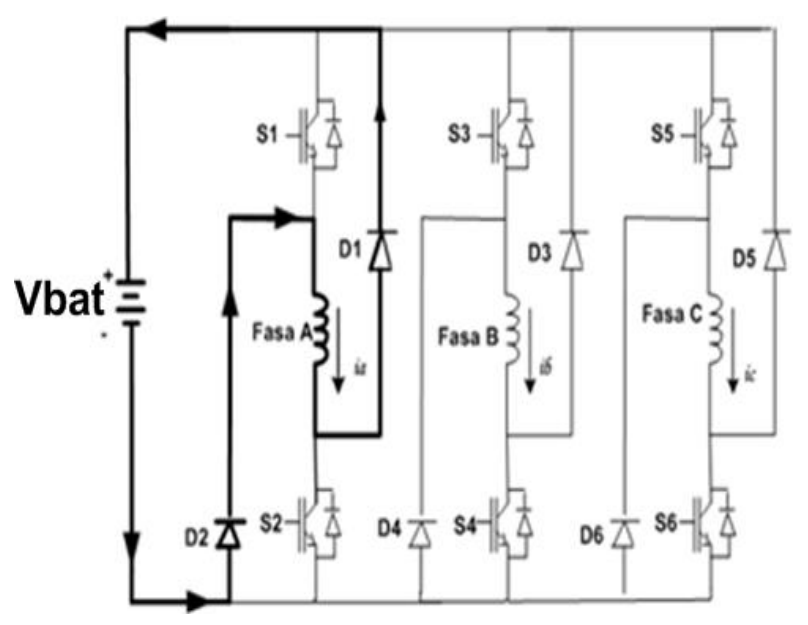

Gambar 6. Mode demagnetisasi pada salah satu fasa

Dari mode operasi magnetisasi dan demagnetisasi dihasilkan pola pensaklaran pulsa tunggal ditunjukkan pada Tabel I. Penelitian ini menggunakan konverter asymmertric yang terdiri dari enam buah saklar dan enam buah dioda pada modul IGBT tipe Semikron serta rangkaian driver dengan menggunakan enam buah TLP 250. Setiap fasa dari SRM memiliki dua buah saklar dan dua buah dioda yang aktif secara bergantian. Blok rangkaian keseluruhan sistem ditunjukkan pada Gambar 7.

TABEL I. POLA PENSAKLARAN PULSA TUNGGAL.

\begin{tabular}{ccccccc}
\hline Fasa & S1 & S2 & S3 & S4 & S5 & S6 \\
\hline A & ON & ON & OFF & OFF & OFF & OFF \\
B & OFF & OFF- & ON & ON & OFF & OFF \\
C & OFF & OFF & OFF & OFF & ON & ON \\
\hline \hline
\end{tabular}



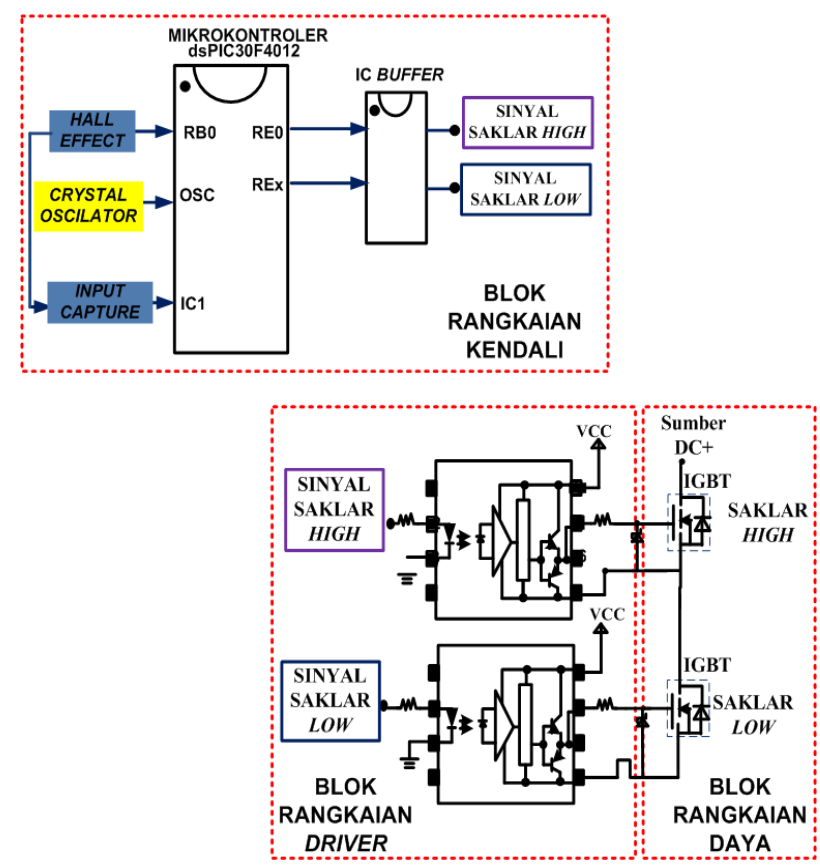

Gambar 7. Blok rangkaian keseluruhan sistem

Gambar 8 menunjukkan rangkaian kendali yang terdiri dari mikrokontroler dan IC buffer. Pola pensaklaran pulsa tunggal diterapkan dengan menggunakan mikrokontroler jenis dsPIC30F4012. Pembangkitan sinyal Pulse Width Modulation (PWM) dari mikrokontroler digunakan untuk proses pensaklaran pada konverter asymmetric yang akan diteruskan menuju IC buffer. IC buffer ini digunakan untuk memberi kestabilan tegangan keluaran dari mikrokontroler untuk diteruskan pada rangkaian driver.

Berdasarkan Gambar 9, mikrokontroler yang digunakan menyediakan fasilitas input capture untuk mengubah nilai $\theta_{\mathrm{eks}}$ dengan pengendalian yang lebih sederhana dibandingkan dengan kendali closed loop [18]. Fasilitas input capture menggunakan timer register yang dibangkitkan dengan referensi sensor hall effect. Hasil dari proses input capture dapat digunakan untuk menentukan $\theta_{\mathrm{eks}}$ dan $\theta_{\text {kom }}$ yang lebih presisi. Input capture interrupt memiliki nilai $360^{\circ}$ elektrik dalam satu putaran rotor dan bergantung pada sinyal dari sensor hall effect [19]. Pada SRM terdapat tiga buah hall effect yang terpasang di sekitar rotor. Salah satu sensor hall effect digunakan sebagai sinyal referensi yang diolah mikrokontroler menjadi nilai integer dan akan dihitung untuk membangkitkan sinyal input capture. Hasil dari proses input capture akan didapatkan $\theta_{\text {eks }}$ dan $\theta_{\text {kom }}$ yang optimal sesuai dengan perhitungan pada (4) dan (5).

$$
\begin{gathered}
\theta_{e k s}=\frac{T_{e k s}}{360} \times \operatorname{Inc} \\
\theta_{k o m}=\frac{T_{e k s}}{360} \times \operatorname{Inc}
\end{gathered}
$$

di mana $T_{e k s}, T_{k o m}$, dan Inc adalah periode waktu sudut eksitasi, periode waktu sudut komutasi, dan nilai input capture interrupt.

Pengujian dilakukan dengan perangkat keras terdiri dari motor Direct Current (DC) sebagai penggerak elektrik. Konverter yang digunakan jenis asymmetric dan kontroler berbasis digital menggunakan mikrokontroler dsPIC30F4012. Mikrokontroler tersebut digunakan untuk memproses hasil pembacaan sensor hall effect sebagai pendeteksi rotor untuk menghasilkan sinyal keluaran pulsa tunggal dalam bentuk PWM yang dapat digunakan untuk menentukan pensaklaran tiap fasa. Blok diagram sistem pengereman regeneratif ditunjukkan pada Gambar 10.

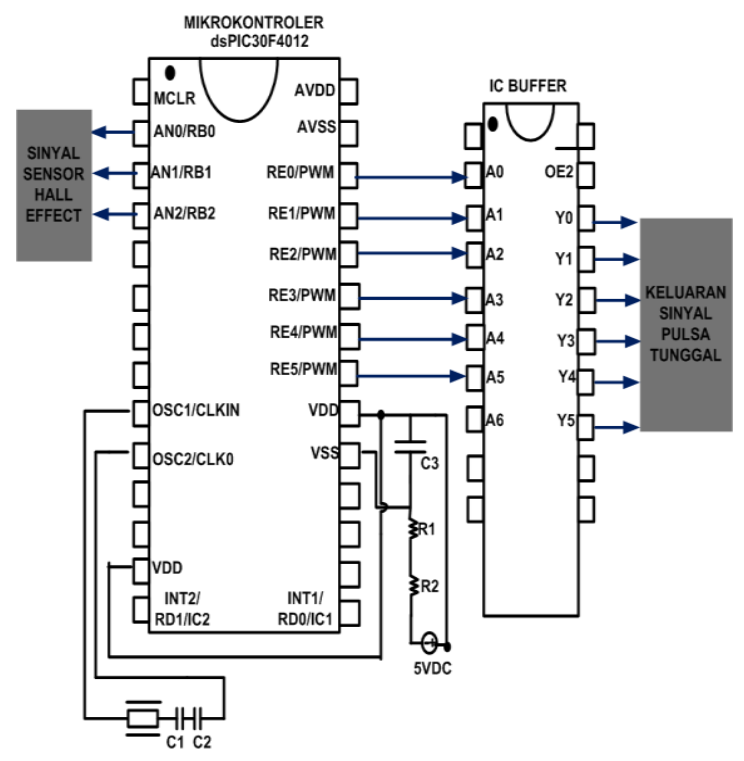

Gambar 8. Rangkaian kendali sistem

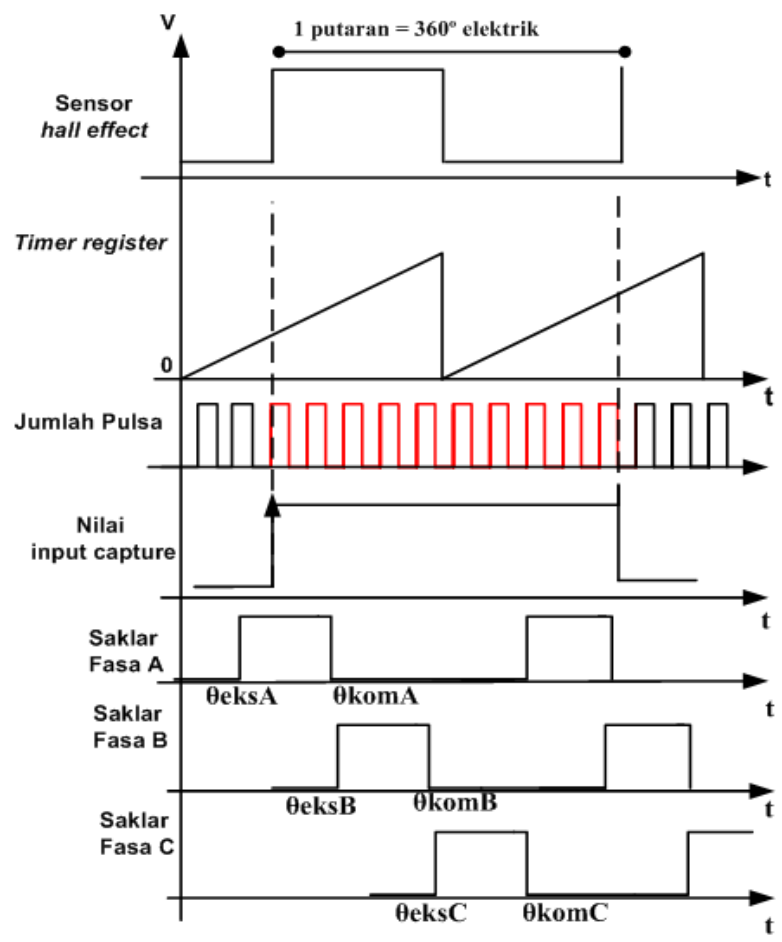

Gambar 9. Proses pensaklaran fasa menggunakan fasilitas input capture dan referensi hall effect.

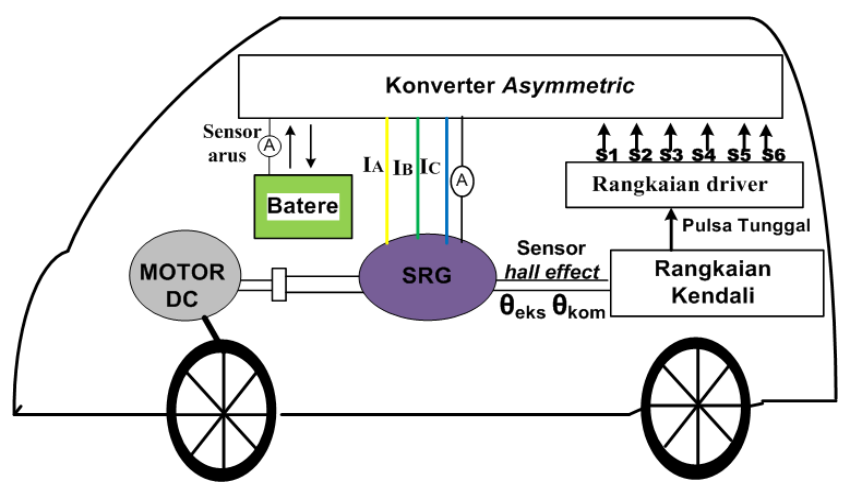

Gambar 10. Diagram blok sistem yang diterapkan pada kendaraan listrik. 
Berdasarkan Gambar 10, langkah awal yaitu motor DC berputar menghasilkan energi kinetik untuk menggerakkan SRM. Putaran dari motor DC akan menggerakkan rotor SRM. Putaran dari rotor SRM berpengaruh pada sensor hall effect yang terpasang diantara stator dan rotor. Sensor hall effect mengirimkan sinyal berupa PWM kepada mikrokontroler dsPIC30F4012 dan akan diolah untuk mengaktifkan fasilitas input capture pada mikrokontroler tersebut. Sinyal dari input capture digunakan untuk menentukan nilai $\theta_{\mathrm{eks}}$ dan $\theta_{\text {komyang }}$ lebih presisi. Penyalaan pada $\theta_{\text {eks }}$ dan pemadaman pada $\theta_{\text {kom }}$ akan menghasilkan pola pensaklaran pulsa tunggal. Pemberian injeksi arus pada stator dilakukan dengan cara memberikan sinyal pensaklaran berupa $\theta_{\text {eks }}$ dan $\theta_{\text {kom }}$ pada posisi induktansi minimum atau pada saat rotor hendak meninggalkan stator. Pola pensaklaran pulsa tunggal yang di program menggunakan perangkat lunak mikro $C$ for $d s P I C$ menghasilkan sinyal saklar yang akan diteruskan ke rangkaian driver dan rangkaian daya sehingga terjadi peningkatan arus fasa. Pengaruh perubahan sudut eksitasi yang terjadi dapat dilihat dari keluaran sensor arus yang diletakkan diantara konverter dengan salah satu belitan SRM. Pada bagian sumber baterai juga dipasang sensor arus untuk mengetahui bentuk arus pada baterai saat charging dan discharging. Untuk memperjelas sistem, flowchart program ditunjukkan pada Gambar 11.

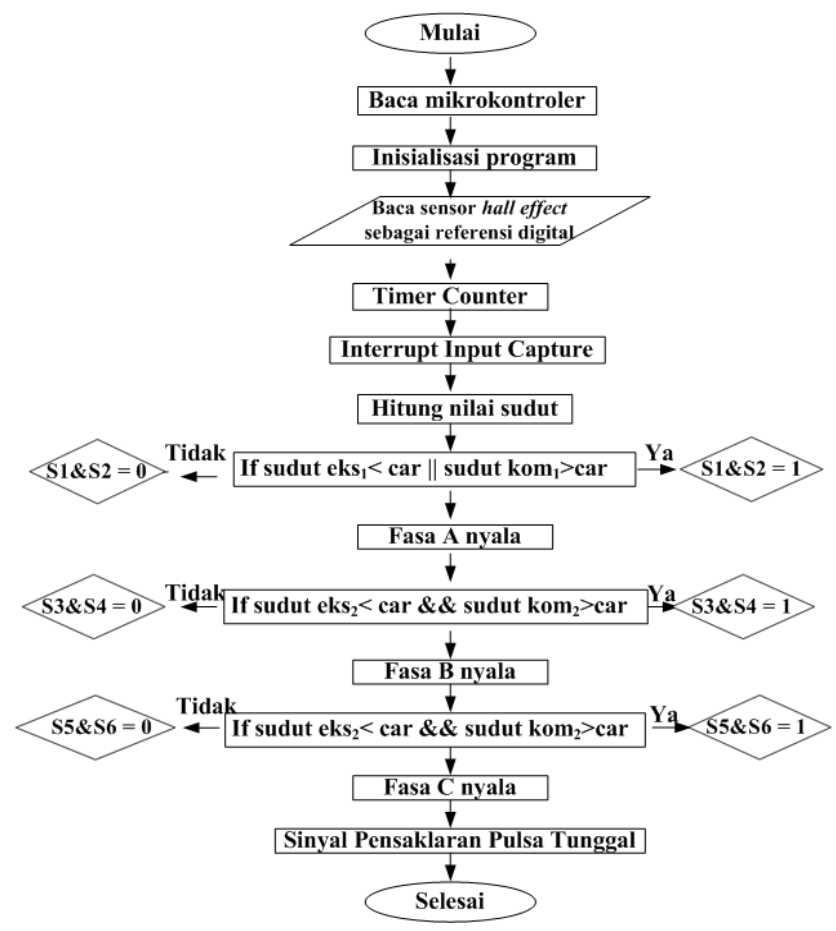

Gambar 11. Flowchart program

\section{HASIL DAN PEMBAHASAN}

Hasil metode yang telah dijabarkan divalidasi dengan simulasi menggunakan Matlab Simulink dan di implementasikan pada perangkat keras agar hasil pengujian sesuai dengan metode. Parameter simulasi yang digunakan pada SRM ditunjukkan pada Tabel II sedangkan parameter implementasi yang digunakan untuk pengujian ditunjukkan pada Tabel III.

Hasil pensaklaran pulsa tunggal pada simulasi diperoleh dari sensor posisi yang terdapat pada SRM. Sensor posisi akan mengirimkan sinyal carrier yang sesuai untuk menentukan nilai $\theta_{\mathrm{eks}}$ dan $\theta_{\text {kom }}$ yang diatur pada blok kendali. Hasil gelombang saklar pulsa tunggal pada simulasi ditunjukkan pada Gambar 12.
TABEL II. SPESIFIKASI SRM PADA SIMULASI

\begin{tabular}{ccc}
\hline \hline Parameter & Nilai & Unit \\
\hline Jumlah fasa & 3 & - \\
Jumlah stator & 6 & - \\
Jumlah rotor & 4 & - \\
Tegangan & 12 & VDC \\
Induktansi & 1,0 & $\mathrm{mH}$ \\
Resistansi & 3,5 & ohm \\
\hline \hline
\end{tabular}

TABEL III. SPESIFIKASI SRM PADA IMPLEMENTASI

\begin{tabular}{ccc}
\hline \hline Parameter & Nilai & Unit \\
\hline Jumlah fasa & 3 & - \\
Jumlah stator & 12 & - \\
Jumlah rotor & 8 & - \\
Tegangan & 12 & VDC \\
Induktansi & 1,4 & $\mathrm{mH}$ \\
Resistansi & 3,3 & ohm \\
\hline \hline
\end{tabular}

Gambar 12 menunjukkan hasil keluaran sinyal saklar pada simulasi. Sensor posisi digunakan sebagai referensi untuk menentukan pensaklaran pada setiap fasa yang dilakukan dengan tiga kondisi yaitu dengan mengubah $\theta_{\mathrm{eks}}$ menghasilkan bentuk gelombang keluaran yang berbeda pada setiap kondisinya. Hasil gelombang keluaran arus baterai, arus fasa, dan tegangan fasa ditunjukkan pada Gambar 12 hingga Gambar 15 .

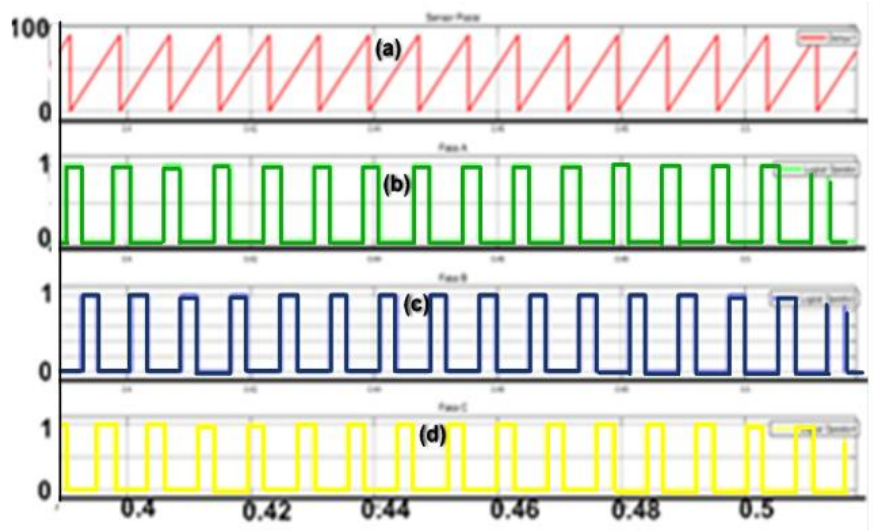

Gambar 12. Hasil sinyal pada simulasi (a) posisi rotor, (b) saklar fasa A, (c) saklar fasa B, dan (d) saklar fasa C.

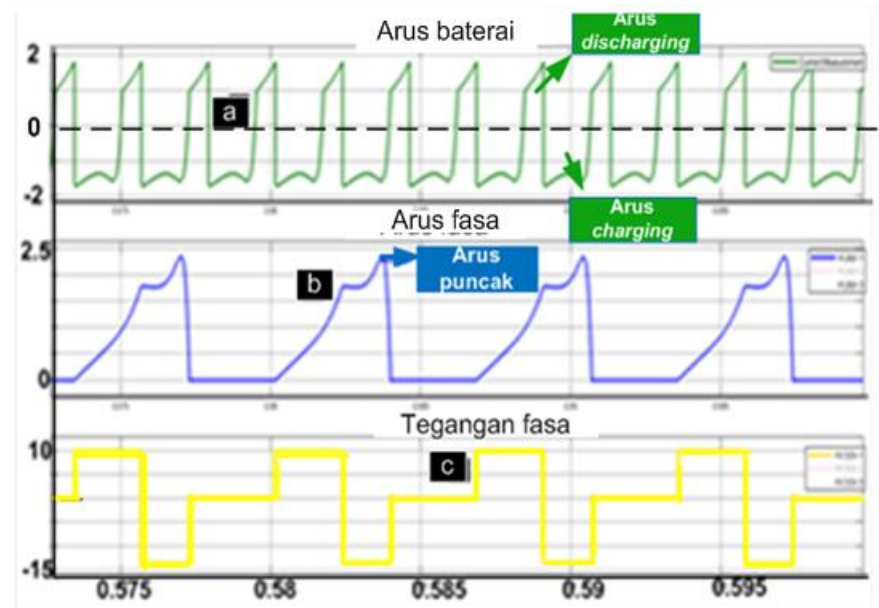

Gambar 13. Hasil gelombang simulasi (a) arus baterai, (b) arus fasa, dan (c) tegangan fasa pada kondisi I $\left(\theta_{\mathrm{eks}}=20^{\circ}\right.$ dan $\left.\theta_{\mathrm{kom}}=50^{\circ}\right)$ 


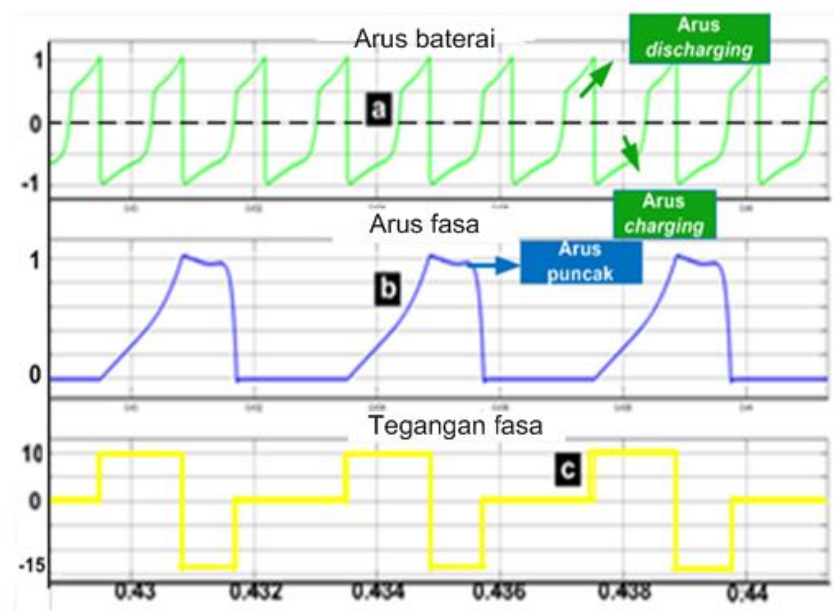

Gambar 14. Hasil gelombang simulasi (a) arus baterai, (b) arus fasa, dan (c) tegangan fasa pada kondisi II $\left(\theta_{\mathrm{eks}}=25^{\circ}\right.$ dan $\left.\theta_{\mathrm{kom}}=50^{\circ}\right)$

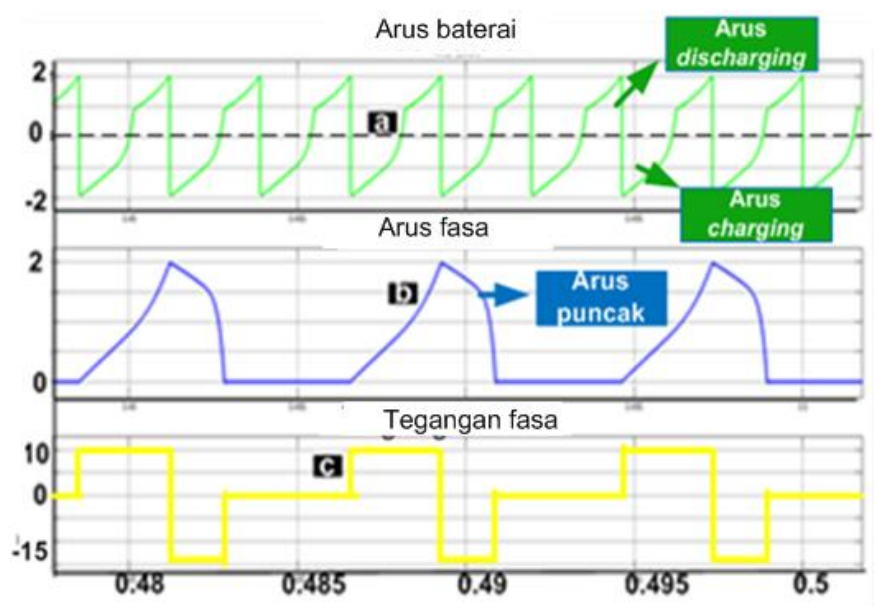

Gambar 15. Hasil gelombang simulasi (a) arus baterai, (b) arus fasa, dan (c) tegangan fasa pada kondisi III $\left(\theta_{\text {eks }}=30^{\circ}\right.$ dan $\left.\theta_{\text {kom }}=170^{\circ}\right)$

Gambar 13 menunjukkan hasil simulasi pada kondisi I dengan nilai menghasilkan arus puncak 2,5A dan dengan bentuk arus fasa yang meningkat. Hal tersebut dikarenakan energi yang dihasilkan dari pengereman lebih besar dari tegangan baterai sehingga adanya energi yang dialirkan ke baterai.

Gambar 14 menunjukkan kondisi II dengan nilai $\theta_{\mathrm{eks}}$ sebesar $25^{\circ}$ dan $\theta_{\text {kom }}$ sebesar $50^{\circ}$ menghasilkan arus puncak sebesar $1 \mathrm{~A}$. bentuk arus fasa yang dihasilkan tidak mengalami peningkatan ataupun penurunan dikarenakan energi yang dihasilkan dari prosess pengereman sama dengan tegangan baterai sehingga tidak ada pengiriman energi ke baterai.

Gambar 15 menunjukkan kondisi III dengan nilai $\theta_{\mathrm{eks}}$ sebesar $30^{\circ}$ dan $\theta_{\text {kom }}$ sebesar $50^{\circ}$ menghasilkan arus puncak sebesar 2A. energi yang dihasilkan dari proses pengereman tidak dapat digunakan untuk pengisian daya ke baterai karena bentuk arus fasa yang mengalami penurunan saat saklar fasa dimatikan.

Hasil perubahan $\theta_{\mathrm{eks}}$ pada simulasi menunjukkan adanya perbedaan pada keluaran gelombang arus fasa dan arus baterai. Pada simulasi kecepatan putar awal yang digunakan sebesar 3000 RPM menghasilkan perbedaan pada keluaran gelombang arus fasa dan arus baterai. Dari ketiga kondisi arus puncak yang dihasilkan paling besar pada simulasi pada kondisi I. Hal tersebut dapat dilihat dari bentuk gelombang arus fasa yang naik.

Pengujian implementasi pada sistem pengereman regeneratif ini dilakukan dua tahap dengan menggunakan pensaklaran pulsa tunggal. Pengujian tahap pertama dilakukan dengan parameter yang diubah adalah nilai $\theta_{\mathrm{eks}}$ sedangkan parameter yang bernilai tetap adalah kecepatan putar rotor dan $\theta_{\text {kom. }}$ Pengujian tahap kedua dilakukan dengan mengubah parameter kecepatan putar rotor sedangkan $\theta_{\mathrm{eks}}$ dan $\theta_{\text {kom }}$ bernilai tetap. Pengujian yang dilakukan menggunakan perangkat keras yang ditunjukkan pada Gambar 16.

Gambar 17 menunjukkan hasil pensaklaran pulsa tunggal pada implementasi yang diperoleh dari sensor hall effect yang terdapat pada SRM. Sensor hall effect yang akan mengirimkan sinyal carrier ke mikrokontroler untuk fasilitas input capture.

Pengujian tahap pertama dilakukan dengan tiga kondisi yaitu mengubah nilai $\theta_{\text {eks }}$ sedangkan nilai $\theta_{\text {kom }}$ dan kecepatan putar awal tetap. Hasil gelombang pada pengujian pertama ditunjukkan pada Gambar 18 hingga Gambar 20.

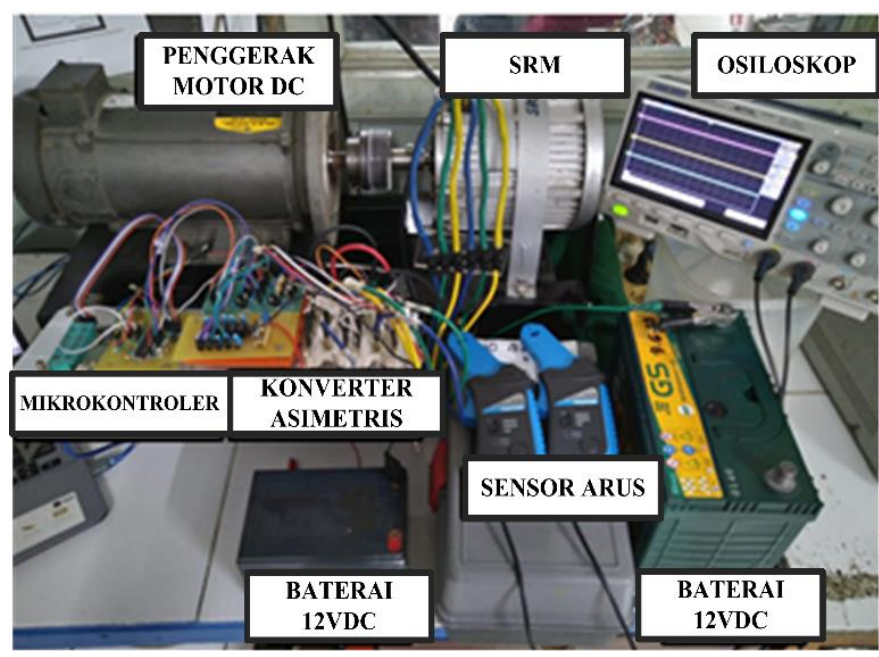

Gambar 16. Pengujian pada perangkat keras

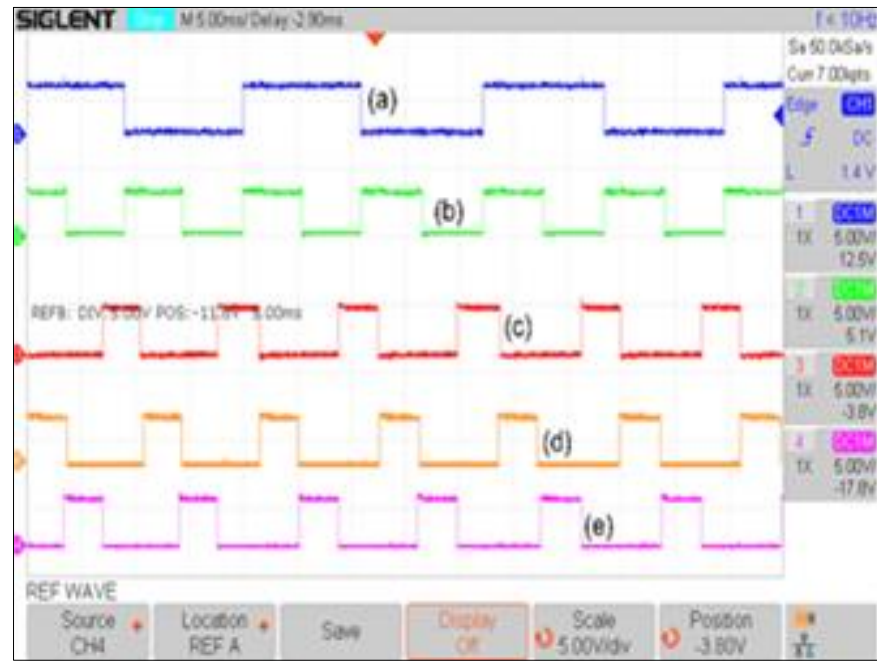

Gambar 17. Hasil sinyal saklar pada implementasi (a) input capture (b) sensor hall effect, (c) saklar fasa A, (d) saklar fasa B, dan (e) saklar fasa C 


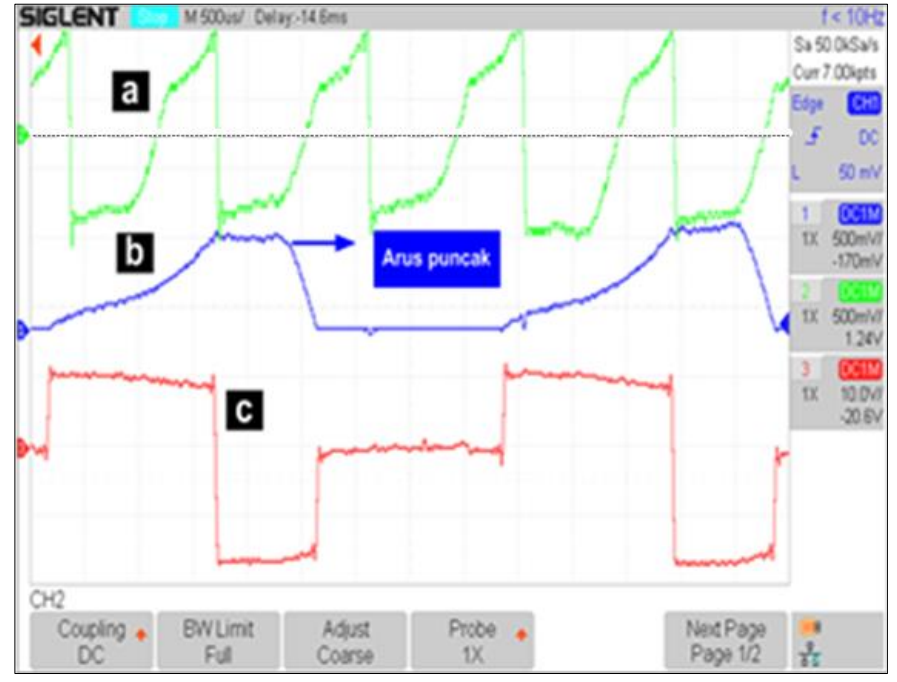

Gambar 18. Hasil gelombang (a) arus baterai, (b) arus fasa, dan (c) tegangan fasa pada kondisi I $\left(\theta_{\text {eks }}=20^{\circ}\right.$ dan $\left.\theta_{\text {kom }}=170^{\circ}\right)$

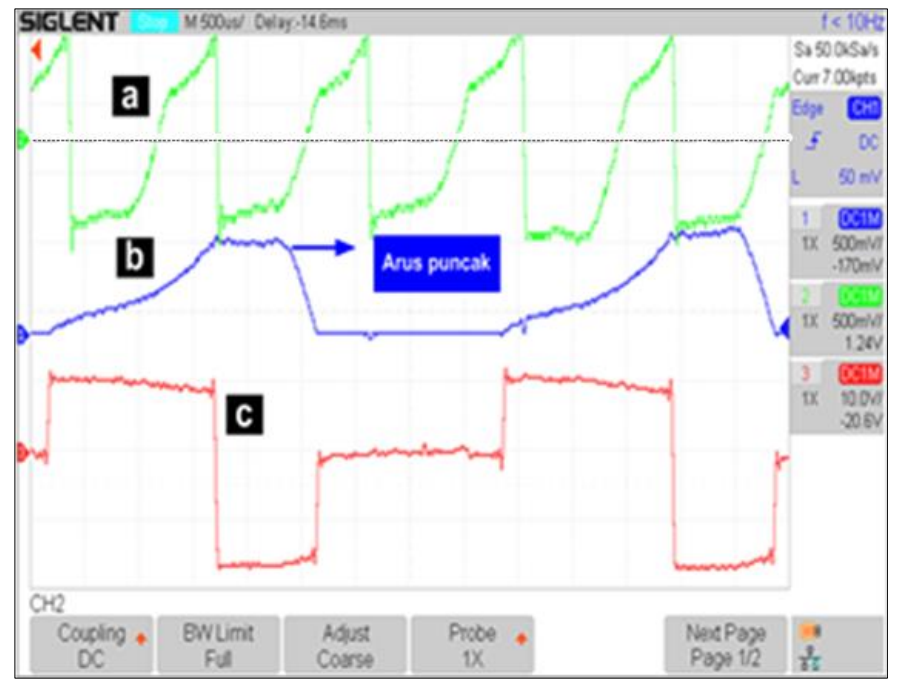

Gambar 19. Hasil gelombang (a) arus baterai, (b) arus fasa, dan (c) tegangan fasa pada kondisi II $\left(\theta_{\mathrm{eks}}=30^{\circ}\right.$ dan $\left.\theta_{\mathrm{kom}}=170^{\circ}\right)$

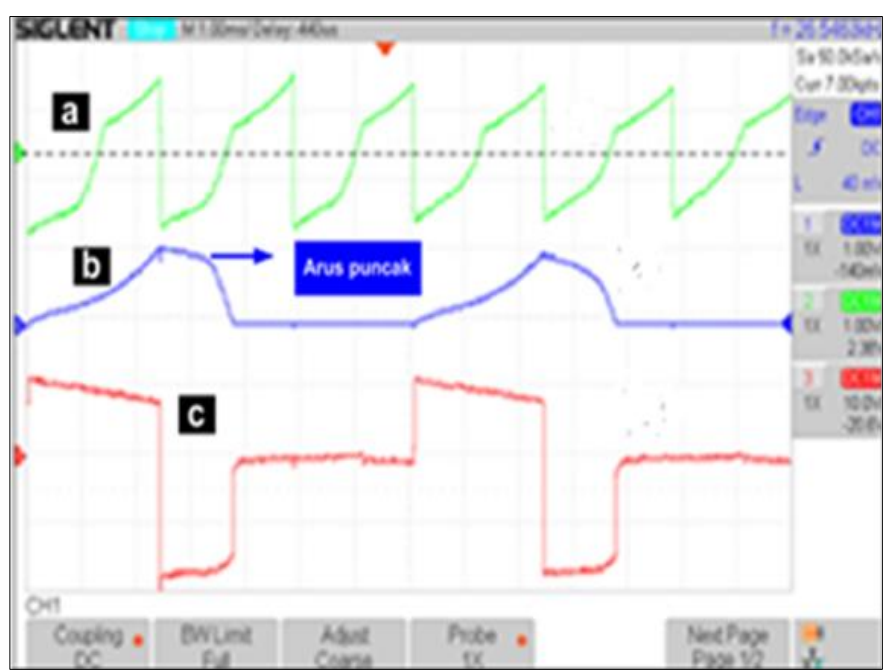

Gambar 20. Hasil gelombang (a) arus baterai, (b) arus fasa, dan (c) tegangan fasa pada kondisi III $\left(\theta_{\mathrm{eks}}=50^{\circ} \theta_{\mathrm{kom}}=170^{\circ}\right)$
Gambar 18 menunjukkan bentuk gelombang arus fasa meningkat setelah saklar fasa dimatikan pada mode demagnetisasi. Pada kondisi I dihasilkan arus puncak sebesar 10 A dengan arus rata-rata 7,5A sehingga adanya arus yang dialirkan ke baterai sebesar 2,5A dari proses pengereman regeneratif. Bentuk gelombang arus baterai yang dihasilkan pada luasan arus charging lebih besar dari luasan arus discharging.

Gambar 19 menunjukkan bentuk gelombang arus fasa tidak mengalami kenaikan atau penurunan sehingga arus bernilai konstan dan GGL balik sama dengan tegangan baterai. Hal tersebut dibuktikan dengan arus rata-rata bernilai 7,5A $\mathrm{A}$ dengan arus puncak yaitu sebesar 7,5A. Pada kondisi II tidak ada arus yang dialirkan ke baterai saat terjadi pengereman.

Gambar 20 menunjukkan terjadi penurunan arus fasa dengan cepat karena arus puncak fasa yang dihasilkan lebih kecil sebesar 5A dari arus rata-rata yaitu 7,5A sehingga tidak ada arus yang dialirkan ke baterai, saat terjadi pengereman.

Hasil pengujian tahap pertama menghasilkan perubahan bentuk arus fasa dan perlambatan kecepatan. Nilai $\theta_{\text {eks }}$ diubah dengan kecepatan awal tetap sebesar 1807 RPM menghasilkan nilai arus puncak fasa dan perlambatan kecepatan yang berbeda ditunjukkan pada Tabel IV.

TABEL IV. HASIL PERUBAHAN SUDUT EKSITASI

\begin{tabular}{cccccc}
\hline \hline Kondisi & $\boldsymbol{\theta}_{\text {eks }}\left({ }^{\circ}\right)$ & $\boldsymbol{\theta}_{\text {kom }}\left({ }^{\circ}\right)$ & $\begin{array}{c}\mathbf{I}_{\text {rata- }} \\
\text { rata }\end{array}$ & $\mathbf{I}_{\text {puncak }}$ & $\begin{array}{c}\text { Kecepatan } \\
\text { pengereman } \\
\text { (RPM) }\end{array}$ \\
\hline I & 20 & 170 & $7,5 \mathrm{~A}$ & $10 \mathrm{~A}$ & 1615 \\
II & 30 & 170 & $7,5 \mathrm{~A}$ & $7,5 \mathrm{~A}$ & 1713 \\
III & 50 & 170 & $7,5 \mathrm{~A}$ & $5 \mathrm{~A}$ & 1746 \\
\hline
\end{tabular}

Pada pengujian tahap kedua juga dilakukan dengan tiga kondisi yaitu dengan menggunakan parameter nilai kecepatan awal yang berbeda sedangkan parameter nilai dari $\theta_{\text {eks }}$ dan nilai $\theta_{\text {kom }}$ tetap. Nilai $\theta_{\text {eks }}$ yang ditetapkan sebesar $20^{\circ}$ dan nilai $\theta_{\text {kom }}$ ditetapkan sebesar $170^{\circ}$. Hasil gelombang keluaran dari pengujian tahap kedua ditunjukkan pada Gambar 21 hingga Gambar 23.

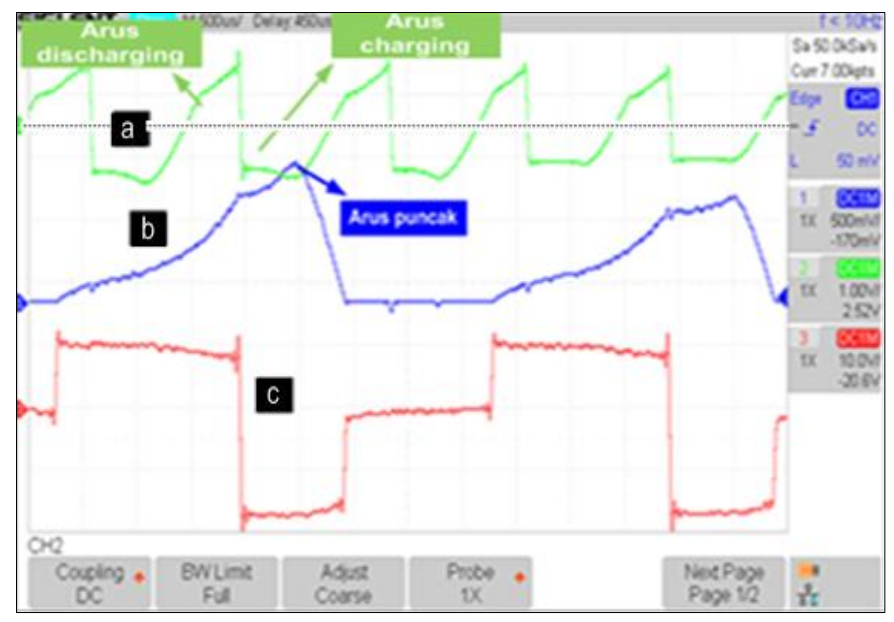

Gambar 21. Hasil gelombang (a) arus baterai, (b) arus fasa, dan (c) tegangan fasa pada kondisi I dengan kecepatan putar awal 1822 RPM 


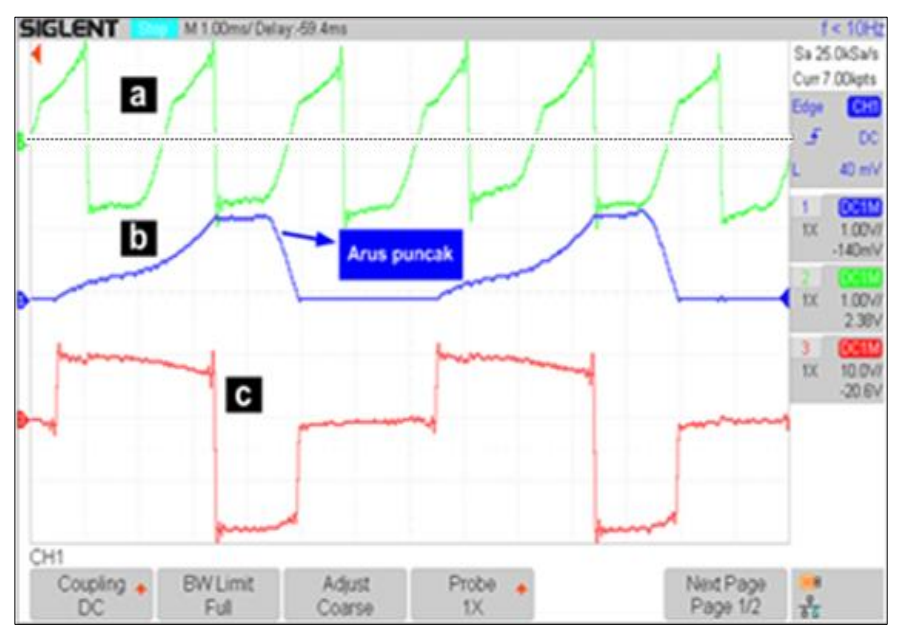

Gambar 22. Hasil gelombang (a) arus baterai, (b) arus fasa, dan (c) tegangan fasa pada kondisi II dengan kecepatan putar awal 1606 RPM

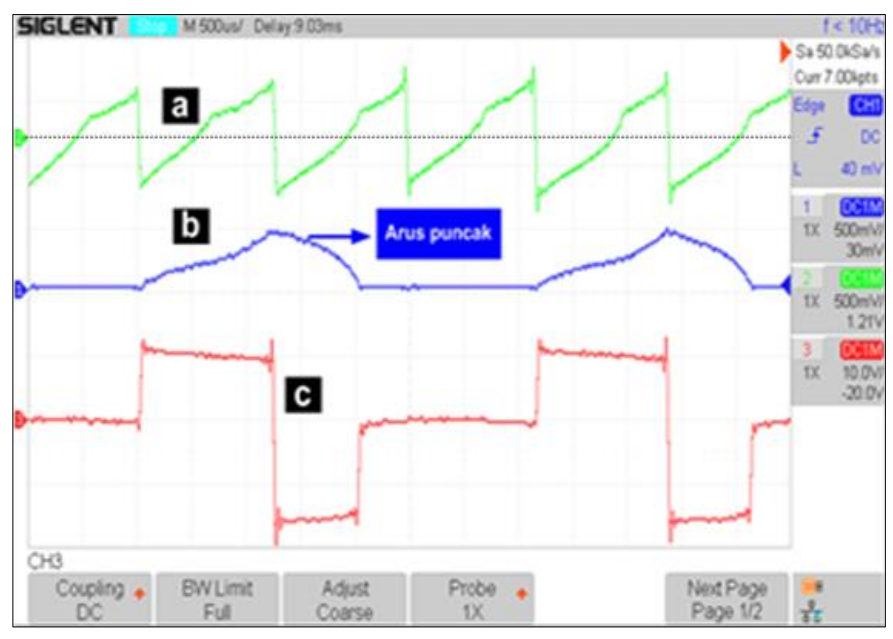

Gambar 23. Hasil gelombang (a) arus baterai, (b) arus fasa, dan (c) tegangan fasa pada kondisi III dengan kecepatan putar awal 1420 RPM

Berdasarkan pengujian tahap kedua, Gambar 21 menunjukkan kondisi I di mana nilai kecepatan putar awal sebesar 1822 RPM mengalami perlambatan kecepatan menjadi 1522 RPM. Bentuk gelombang arus fasa menunjukkan kemiringan arus fasa naik sehingga menghasilkan arus puncak sebesar 12,5A dengan arus rata-rata sebesar 7,5A sehingga adanya aliran arus yang dikembalikan ke baterai sebesar $5 \mathrm{~A}$ saat terjadi pengereman.

Gambar 22 menunjukkan kondisi II di mana nilai kecepatan putar awal rotor sebesar 1606 RPM mengalami perlambatan kecepatan menjadi 1445 RPM. Bentuk arus fasa yang dihasilkan menunjukan kemiringan arus fasa konstan di mana tidak terjadi peningkatan atau penurunan sehingga arus ratarata sama dengan arus puncak yaitu sebesar 7,5A sehingga tidak ada arus yang dialirkan ke baterai.

Gambar 23 menunjukkan kondisi III dengan kecepatan putar awal sebesar 1420 RPM mengalami perlambatan kecepatan menjadi 1215 RPM. Bentuk arus fasa menunjukkan kemiringan arus fasa menurun. Hal tersebut dibuktikan dengan nilai arus puncak sebesar $5 \mathrm{~A}$ dengan nilai arus rata-rata sebesar 7,5A. Nilai arus puncak yang dihasilkan lebih kecil dari arus rata-rata sehingga tidak ada arus yang dialirkan ke baterai.

Dari hasil pengujian tahap kedua terbukti bahwa nilai kecepatan yang tinggi akan dihasilkan arus puncak yang lebih besar dari arus rata-rata. Semakin tinggi nilai kecepatan putar rotor maka semakin besar nilai arus puncak fasa yang dihasilkan, hal tersebut dapat dibuktikan pada pengujian tahap kedua pada kondisi I. Hasil dari pengujian tahap kedua ditunjukkan pada Tabel V.

TABEL V. HASIl PERUBAHAN KeCEPATAN

\begin{tabular}{ccccc}
\hline \hline Kondisi & $\begin{array}{c}\text { Kecepatan } \\
\text { putar } \\
\text { awal } \\
\text { (RPM) }\end{array}$ & $\begin{array}{c}\text { Kecepatan setelah } \\
\text { terjadi } \\
\text { pengereman } \\
\text { (RPM) }\end{array}$ & $\begin{array}{c}\mathbf{I}_{\text {rata- }} \\
\text { rata } \\
\text { (A) }\end{array}$ & $\begin{array}{c}\mathbf{I}_{\text {puncak }} \\
\text { (A) }\end{array}$ \\
\hline I & 1822 & 1522 & 7,5 & 12,5 \\
II & 1606 & 1445 & 7,5 & 7,5 \\
III & 1420 & 1215 & 7,5 & 5 \\
\hline \hline
\end{tabular}

Hasil pengujian tahap pertama dan tahap kedua yang berhasil digunakan pada sistem pengereman regeneratif yaitu pada kondisi I. Pada pengujian pertama arus puncak yang dihasilkan sebesar 10A dan arus sebesar 2,5A dialirkan ke baterai saat terjadi pengereman. Sedangkan pada pengujian kedua menghasilkan arus puncak sebesar 12,5A dengan arus sebesar 5A dialirkan ke baterai saat terjadi pengereman.

Metode perubahan sudut pada SRM banyak dikembangkan dengan menggunakan kendali closed loop [18]. Nilai sudut fasa yang tidak tepat akan menghasilkan nilai arus puncak yang kecil [20]. Hasil yang telah dicapai adalah mengubah sudut eksitasi dengan menggunakan fasilitas input capture mampu menghasilkan arus puncak yang lebih besar dari penelitian sebelumnya yaitu SRM menggunakan metode perubahan sudut eksitasi yang hanya menghasilkan arus puncak sebesar 9A [20]. Penelitian ini mampu menghasilkan arus puncak paling besar yaitu 12,5A dan arus yang dikembalikan ke baterai sebesar 5A saat terjadi pengereman. Hal tersebut menunjukan adanya pengereman regeneratif yang optimal.

Pada pengujian pertama metode yang digunakan mengubah sudut eksitasi dengan kecepatan tetap. Pengaturan sudut diperoleh berdasarkan profil induktansi. Pada sistem pengereman regeneratif nilai $\theta_{\mathrm{eks}}$ dan nilai $\theta_{\mathrm{kom}}$ diatur pada saat induktansi turun agar menghasilkan torka negatif sehingga terjadi perlambatan kecepatan. Nilai sudut eksitasi yang tepat akan menghasilkan nilai arus puncak yang besar sehingga energi yang terbuang akibat proses pengereman diubah oleh generator menjadi bentuk arus yang dapat dialirkan ke sisi baterai. Nilai sudut eksitasi yang kurang tepat mengakibatkan nilai arus puncak kecil dan nilai kecepatan pengereman dalam bentuk arus dan nilai kecepatan pengereman kecil.

Sedangkan pada pengujian kedua metode yang digunakan mengubah kecepatan putar awal sedangkan nilai sudut eksitasi tetap. Nilai sudut eksitasi yang ditentukan merupakan nilai sudut eksitasi yang tepat. Semakin tinggi nilai kecepatan putar awal akan menghasilkan nilai arus puncak dan nilai kecepatan pengereman yang besar. Energi dari pengereman inilah yang akan digunakan untuk pengisian daya ke baterai.

\section{IV.PENUTUP}

Konsep pengereman regeneratif telah diuraikan pada penelitian ini. Tahap pengujian implementasi dilakukan dengan dua tahap. Tahap pertama dilakukan dengan mengubah sudut eksitasi. Nilai sudut diperoleh berdasarkan profil induktansi pada SRM. Sistem pengereman regeneratif dengan pengaturan sudut dilakukan pada saat nilai induktansi menurun yang menghasilkan torka negatif sehingga terjadi perlambatan kecepatan. Pengujian pertama menghasilkan nilai $\theta_{\mathrm{eks}}$ yang tepat yaitu $20^{\circ}$ sedangkan nilai $\theta_{\text {kom }}$ yaitu $170^{\circ}$ dengan kecepatan putar awal sebesar 1807 RPM menjadi 1615 RPM yang menghasilkan arus puncak sebesar 10A dan arus sebesar 2,5A dialirkan ke baterai saat terjadi pengereman regeneratif. 
Pada pengujian kedua menggunakan kecepatan sebesar 1822 RPM menghasilkan arus puncak maksimal sebesar 12,5A dan arus yang dialirkan ke baterai sebesar $5 \mathrm{~A}$. Hasil pengujian yang dilakukan menunjukkan bahwa perubahan nilai $\theta_{\mathrm{eks}}$ dan nilai kecepatan awal berpengaruh pada sistem pengereman regeneratif. Nilai $\theta_{\text {eks }}$ yang sesuai dan nilai kecepatan yang tinggi dapat menghasilkan pengereman regeneratif yang optimal hal tersebut dibuktikan dengan besarnya nilai arus yang dialirkan ke sisi baterai saat terjadi pengereman.

\section{UCAPAN TERIMA KASIH}

Direktorat Riset dan Pengabdian Masyarakat, Deputi Bidang Pengutan Riset dan Pengembangan Kementrian Riset dan Teknologi/Badan Riset dan Inovasi Nasional sesuai dengan Kontrak Pelaksanaan Program Penelitian Nomor: 312/SP2H/LT/DRPM/2021 atas dukungan dana penelitian.

\section{REFERENSI}

[1] A. Eldho Aliasand and F. T. Josh, "Selection of Motor foran Electric Vehicle: A Review," Mater. Today Proc., vol. 24, pp. 1804-1815, 2020, doi: 10.1016/j.matpr.2020.03.605.

[2] J. Riset, A. W. Aditya, R. M. Utomo, J. Soekarno, and H. Km, "Evaluasi Motor Listrik Sebagai Penggerak Mobil Listrik Evaluation of Electric Motor as The Main Actuator of Electric Vehicle," 2019, vol. 3, no. 2, pp. 55-59, doi: 10.30595/jrst.v3i2.4142.

[3] M. Korkosz and A. Powrózek, "The influence of control parameters on energy efficiency of switched reluctance generator for vehicle applications," E3S Web Conf., vol. 14, p. 01037, Mar. 2017, doi: 10.1051/e3sconf/20171401037.

[4] R. Munarto and B. Rinaldi, “Analisis Pengereman dinamik pada Motor Induksi 3 Fasa dengan metode Injeksi Arus Searah dan Kapasitor Eksitasi Sendiri Fuzzy C-Means Clustering," Setrum Sist. KendaliTenaga-Elektronika-Telekomunikasi-Komputer, vol. 7, no. 1, p. 69, 2018, doi: 10.36055/setrum.v7i1.3462.

[5] D. Prameswari and Y. Yohanes, "Analisa Sistem Pengereman Pada Mobil Multiguna Pedesaan,” J. Tek. ITS, vol. 8, no. 1, Jun. 2019, doi: 10.12962/j23373539.v8i1.42494.

[6] Z. Zhang, R. Ma, L. Wang, and J. Zhang, "Novel PMSM Control for Anti-Lock Braking Considering Transmission Properties of the Electric Vehicle," IEEE Trans. Veh. Technol., vol. 67, no. 11, pp. 10378-10386, Nov. 2018, doi: 10.1109/TVT.2018.2866828.

[7] P. H. Simbolon and A. B. Pulungan, "Implementasi Buck-Boost Converter pada Proses Pengereman Regeneratif Motor BLDC," J. Teknol. dan Rekayasa Manufaktur, vol. 2, no. 2, pp. 19-28, Oct. 2020, doi: 10.48182 /jtrm.v2i2.77.

[8] M. D. Rivandi, "Studi Analisis Daya Hasil Proses Regeneratif Motor Elevator," Progr. Stud. Tek. elektro ISTN, Jakarta selatan, vol. XIX, no. 1, pp. 27-32, 2017.
[9] M. Latif, A. Valdesio, and M. Muharam, "Energi Listrik dari Pengereman Regeneratif Sepeda Motor dengan Menggunakan Dinamo Sepeda," J. Nas. Tek. ELEKTRO, vol. 7, no. 2, p. 90, Jul. 2018, doi: 10.25077/jnte.v7n2.503.2018.

[10] T. A. D. S. Barros, P. J. D. S. Neto, P. S. N. Filho, A. B. Moreira, and E. R. Filho, "An Approach for Switched Reluctance Generator in a Wind Generation System with a Wide Range of Operation Speed," IEEE Trans. Power Electron., vol. 32, no. 11, pp. 8277-8292, 2017, doi: 10.1109/TPEL.2017.2697822.

[11] P. J. D. S. Neto, T. A. D. S. Barros, M. V. De Paula, R. R. De Souza, and E. R. Filho, "Design of Computational Experiment for Performance Optimization of a Switched Reluctance Generator in Wind Systems," IEEE Trans. Energy Convers., vol. 33, no. 1, pp. 406-419, 2018, doi: 10.1109/TEC.2017.2755590.

[12] W. Uddin, T. Husain, Y. Sozer, and I. Husain, "Design Methodology of a Switched Reluctance Machine for Off-Road Vehicle Applications," IEEE Trans. Ind. Appl., vol. 52, no. 3, pp. 2138-2147, May 2016, doi: 10.1109/TIA.2015.2514283.

[13] W. Uddin, T. Husain, Y. Sozer, and I. Husain, "Design Methodology of a Switched Reluctance Machine for Off-Road Vehicle Applications," IEEE Trans. Ind. Appl., vol. 52, no. 3, pp. 2138-2147, May 2016, doi: 10.1109/TIA.2015.2514283.

[14] V. P. Vujicic and M. P. Calasan, "Simple Sensorless Control for HighSpeed Operation of Switched Reluctance Generator," IEEE Trans. Energy Convers., vol. 31, no. 4, pp. 1325-1335, Dec. 2016, doi: 10.1109/TEC.2016.2571841.

[15] Y. Zhu, H. Wu, and J. Zhang, "Regenerative Braking Control Strategy for Electric Vehicles Based on Optimization of Switched Reluctance Generator Drive System,” IEEE Access, vol. 8, pp. 76671-76682, 2020, doi: 10.1109/ACCESS.2020.2990349.

[16] S. S. Ahmad and G. Narayanan, "Modeling of Single-Pulse Operated Switched Reluctance Generator and Its Verification," IEEE Trans. Ind. Appl., vol. 56, no. 5, pp. 4966-4976, Sep. 2020, doi: 10.1109/TIA.2020.3005586.

[17] M. Ma, Z. Chang, Y. Hu, F. Li, C. Gan, and W. Cao, "An Integrated Switched Reluctance Motor Drive Topology with Voltage-Boosting and On-Board Charging Capabilities for Plug-In Hybrid Electric Vehicles (PHEVs)," IEEE Access, vol. 6, pp. 1550-1559, 2017, doi: 10.1109/ACCESS.2017.2779460.

[18] A. Yousefi-Talouki, P. Pescetto, G. Pellegrino, and I. Boldea, "Combined Active Flux and High-Frequency Injection Methods for Sensorless Direct-Flux Vector Control of Synchronous Reluctance Machines," IEEE Trans. Power Electron., vol. 33, no. 3, pp. 2447-2457, Mar. 2018, doi: 10.1109/TPEL.2017.2697209.

[19] V. Wijaya and S. Riyadi, "Implementation of Input Capture Method on Switched Reluctance Motor to Obtain Precise Commutation Signals," CENCON 2019 - 2019 IEEE Conf. Energy Convers., vol. 2019-Janua, pp. 110-114, 2019, doi: 10.1109/CENCON47160.2019.8974776.

[20] E. Roshandel, M. M. Namazi, A. Rashidi, S. M. Saghaian-Nejad, and J. W. Ahn, "SSC strategy for SRG to achieve maximum power with minimum current ripple in battery charging," IET Electr. Power Appl., vol. 11, no. 7, pp. 1205-1213, 2017, doi: 10.1049/iet-epa.2016.0770. 